which they asked should do so immediately, especially if they wish to take courses in the London area or in Stoke.

\section{Conference on Infestation of Stored Foodstuffs}

The Food and Agriculture Organisation of the United Nations has invited its forty-seven member Governments to send experts to meet in London during August 5-12, for a conference on the problems of infestation of stored foodstuffs. This term includes food undergoing transit, storage and processing. Problems to be studied include measures to prevent infestation such as adequate improved warehousing facilities, as well as a study of methods of pest control used in the various countries. Also to be investigated are world foci of infestation and the channels through which insects, mites, rodents and mould fungi are carried in foodstuffs to all parts of the world. Aspects of the production, availability, and consumption of insecticides, fungicides, fumigants and rodent poisons will also be examined. An attempt will be made to obtain some idea of the extent of the very grave losses which are known to occur through infestation, and to recommend measures which could be applied to prevent these losses. A report of the recommendations of the meetings will be submitted by the Food and Agriculture Organisation to all member Governments and to other interested international agencies.

\section{Congress of the Universities of the British Empire}

IT is announced that, at the invitation of the University of Oxford, the next Congress of the Universities of the Empire will be held in Oxford during July 19-23, 1948. The Universities Bureau of the British Empire is requesting each of its member institutions to appoint four delegates, and although present conditions have necessitated this limitation of numbers, it is expected that about three hundred senior teaching and administrative officers will attend as representatives of universities and other institutions of higher learning, both home and overseas. The subjects for discussion at the various sessions will be announced later.

There have been five previous congresses, the first having been held in London in 1912 as the result of a resolution adopted by the Senate of the University of London in 1909. All the universities of the Empire sent delegates to that meeting, when it was agreed to establish the Universities Bureau in London and to hold congresses regularly every five years for the discussion of questions of academic policy of common interest. The two World Wars have interrupted this quinquennial programme of meetings; but congresses were held in 1921 (at Oxford), 1926 (at Cambridge), 1931 (at Edinburgh), and 1936 (at Cambridge). The 1948 gathering will therefore be the first general meeting for twelve years of official representatives of the universities of the British Commonwealth and Empire.

\section{University of Glasgow: Chair of Physiological Chemistry}

Prof. James Norman Davidson has been appointed to the Gardiner chair of physiological chemistry in succession to Prof. G. M. Wishart. Prof. Davidson graduated in chemistry at Edinburgh in 1934, and later took the degrees of M.D. (1939) and D.Sc. (1945). During 1937-38 he worked with
Warburg at the Kaiser Wilhelm Institute for Cell Physiology. He has held lectureships in biochemistry at Dundee and St. Andrews; has been on the scientific staff of the Medical Research Council ; and for the past year has been professor of biochemistry at St. Thomas' Hospital Medical School, London (see Nature, 157, 760 ; 1946). His research work touches on many fields, including those of carbohydrate metabolism and of the nucleic acids.

\section{Announcements}

Sir Alexander Fleming and Sir Howard Florey have each been awarded the Gold Medal of the Royal Society of Medicine for their work on penicillin. The Medal is normally given once in three years, but on this occasion two were awarded.

Dr. John H. Lawrence, of the University of California, will deliver the twenty-fourth Mackenzie Davidson Memorial Lecture at the British Institute of Radiology on July 17, at 8 p.m., in the Reid-Knox Hall, 32 Welbeck Street, W.1. He will speak on "The Application of Artificial Radioactivity to Biology and Medicine".

Mr. Harold Claughton is retiring from the post of principal of the University of London on December 31 , and the Senate, with the concurrence of the Court, has appointed Dr. D. W. Logan, clerk of the University Court since 1944, to succeed him.

Aт the University of Aberdeen on July 3 the honorary degree of LL.D. was conferred on Prof. C. D. Broad, Knightsbridge professor of moral philosophy in the University of Cambridge. Among other degrees conferred was that of Ph.D. on K. Hassan for a thesis on "Factors affecting the Utilization of Phosphorus in the form of Phytic Acid by the Ruminants" ; and M.D. on L. D. M. Gavin for a thesis on "The Military Malaria Campaign in Greece, 1945".

THE following elections to the Paris Academy of Sciences have been announced: M. Pierre Teilhard de Chardin, Gaston Delépine, of Lille, and Prof. Pierre Pruvost, professor of geology and mineralogy in the University of Lille, correspondants for the Section of Mineralogy ; Prof. H. A. Kramers, professor of mathematical physics in the University of Leyden, and Prof. René de Mallemann, professor of physics in the University of Nancy, correspondants for the Section of General Physics; Prof. Emile Briner, professor of theoretical and technical chemistry in the University of Geneva, Dr. C. H. Desch, honorary scientific adviser to the Iron and Steel Research Council, and Prof. Hans von Euler, professor of chemistry in the Stockholms Högskola, correspondants for the Section of Chemistry.

Mr. G. F. Cole, who for the past year has acted as assistant secretary of the Illuminating Engineering Society, has now been appointed secretary of the Society.

THE following appointments have been made in the Colonial Service: A. B. Cahusac, assistant conservator of forests, Uganda; M. S. Philip, assistant conservator of forests, Uganda; A. C. M. McKinlay, geologist, Tanganyika Territory; R. K. J. Gascoigne (agricultural officer, Nigeria), entomologist, East African Anti-Locust Directorate, Kenya. 